\title{
Corporate Entrepreneurship in Lithuanian Mature Organisations: is it Really Working?
}

\author{
Jurga Duobiene
}

\author{
Kaunas University of Technology \\ Gedimino st. 50, LT-44029, Kaunas, Lithuania \\ E-mail.jurga.duobiene@ktu.lt
}

cross $^{\text {ref }}$ http://dx.doi.org/10.5755/j01.ee.28.1.10297

\begin{abstract}
Innovations are necessary for successful competition in local and global markets; moreover, they are at the core of corporate entrepreneurship (CE). The paper deals with corporate entrepreneurship in mature organisations. The theoretical model of $C E$, including innovations, strategic objectives and potential for growth, is described in the article. It is different from common approaches to $C E$ in the field by attributing characteristics frequently used in CE research to institutional factors of CE. Three institutional factors and their relations with CE are analysed: managers' attitudes toward entrepreneurship, entrepreneurial culture and institutional support systems. Medium and large sized Lithuanian mature organisations have been researched in regard to $C E$ and its factors using the random sampling method and online survey.

The results have shown that Lithuanian mature organisations reveal a high level of CE; however, innovations are at the lowest level in comparison with the other two characteristics of CE. Managers' attitudes toward entrepreneurship, entrepreneurial culture and institutional support systems positively correlate with CE, but the strength of correlation is different. The results have disclosed the importance of managers' attitudes toward entrepreneurship to institutional support systems and entrepreneurial culture as well as the importance of managers' attitudes toward entrepreneurship to CE through the moderating effect of institutional support systems and entrepreneurial culture.
\end{abstract}

Keywords: Corporate Entrepreneurship, Institutional Factors, Managers' Attitudes Toward Entrepreneurship, Entrepreneurial Culture, Institutional Support Systems, Mature Organisations, Lithuania.

\section{Introduction}

In a global world, competition forces organisations to continuously innovate in the internal and external environment. Internally, they generate new ideas, develop new products, change processes and structures, while externally they innovate in marketing, resource acquisition, development of new ventures, etc. Matson's (1996) statement about the core question on inventing or dying shows that innovations have become the blood of organisations. Further research has confirmed the impact of innovations on national and global economies (de la Mothe \& Paquet, 1998; Boekema et al., 2000, Zhao, 2005; Murphy et al., 2006) as well as on corporate performance (Beer et al., 1990; Zahra, 1991; Hornsby et al., 1999; Zahra \& Covin, 1995; Lyon et al., 2000).

CE is based on innovations (Schollhammer, 1982; Zahra, 1993; Lumpkin \& Dess, 1996; Antoncic \& Hisrich, 2004; Zhao, 2005; Rutherford \& Holt, 2007) and it can contribute to corporate success. However, the discussion in the field is still going on in regard to CE domain (Covin \& Slevin, 1991; Lumpkin \& Dess, 1996; Sharma \& Chrisman, 1999), measurement (Kuratko et al., 1990; Antoncic \& Hisrich, 2001; Rutherford et al., 2003; Covin \& Wales, 2011) and CE factors (Russell, 1989; Zahra et al., 2004; Antoncic, 2007; Hornsby et al., 1993, 2009; Ling et al., 2008; Ireland et al., 2009). CE research of the activities implemented by mature organisations is rare (Miller \& Freisen, 1984; Russell, 1990; Rutherford et al., 2003) but essential as the next organisational life cycle of such organisations might not lead to renewal but to decline. Thus, the research question of the paper is formulated as follows: how is CE expressed in mature organisations and how can it be developed? The aim of the paper is to present a theoretical framework of CE and discuss the results of empirical research in Lithuanian mature organisations.

Lithuania is in transition to innovation driven economy (Singer et al., 2014). Thus, the need of CE research is continually growing. However, Lithuanian researchers are oriented towards doing research on strategic entrepreneurship (Jucevicius, 1999; Uus \& Monkeviciene, 2005; Andriuscenka, 2003; Krisciunas \& Greblikaite, 2007; Vaitkevicius \& Binkeviciute, 2007), entrepreneurship in SMEs (Bartkus, 2004; Andriuscenka \& Adamoniene, 2006; Zukauskas \& Stripeikis, 2011), development of individual entrepreneurship (Strazdiene \& Garalis, 2007, Greblikaite \& Krisciunas, 2012; Paulioniene, 2007), entrepreneurship in specific business sectors or its specific implementation (Gronskas, 2000; Grundey \& Sarvutyte, 2007; Startiene \& Remeikiene, 2008; Petuskiene \& Glinskiene, 2011) and individual entrepreneurship (Krisciunas \& Cepkauskiene, 2004; Vazdonis \& Ciutaite, 2010) rather than research on CE. Lithuanian researchers analyse CE merely as a theoretical issue in parts of broader research (Snitka \& Gerdvilas, 2001; Andriuscenka; 2003; Zidonis, 2008). Therefore, the present research on $\mathrm{CE}$ in Lithuanian organisations contributes to the development of this research area in the country as well as provides the knowledge about the current status and possibilities to develop $\mathrm{CE}$ in Lithuanian mature organisations.

\section{Theoretical Framework of CE}

According to Wickham (2004), the concepts of entrepreneurial venture, entrepreneurial organisation and usual small business venture organisations differ in three 
characteristics: innovations, strategic objectives and potential for growth. Despite the fact that this framework was not designed for $\mathrm{CE}$, it fully refers to the main features of CE. Innovations are in the core of CE (Schollhammer, 1982; Zahra, 1993; Lumpkin \& Dess, 1996; Antoncic \& Hisrich, 2004; Zhao, 2005; Rutherford \& Holt, 2007), but the question is how to research them as numbers reveal only one aspect of this characteristic. Wickham (2004) emphasises the significance of innovations and states that significant innovations are the key for success. Though, Miller \& Friesen (1984) note that mature organisations develop fewer radical innovations than organisations in other stages of organisational life-cycle.

Moreover, entrepreneurial organisations usually go beyond small business venture because of formally articulated strategic objectives, including growth target, market development, market share or market position (Wickham, 2004). Strategy is also emphasised in CE research: Vesper (1984) indicates the importance of strategic goals; Guth \& Ginsberg (1990), Covin \& Miles (1999) distinguish strategic renewal and mention a large extent of other types of CE that could also be related to strategy. Antoncic \& Hisrich (2001), Antoncic (2007) do not directly mention strategy, but organisational self-renewal is always related with changes in the strategy.

Growth is another CE characteristic proposed by Wickham (2004). New business venturing (Antoncic, 2007), entering new markets (creation of new product market arena) (Covin \& Slevin, 1999) and corporate venturing (Guth \& Ginsberg, 1990; Sharma \& Chrisman, 1999) are related to CE and represent the antecedents of business growth.

Regarding Lithuanian organisations and corporate entrepreneurship, the research (Duobiene; 2013) shows that Lithuanian organisations have the highest potential for growth in the maturity stage in comparison with other characteristics of CE. Innovations have been assessed to be at the lowest level, but higher than in other stages of organisational life-cycle. The results have also shown that CE in Lithuanian mature organisation is high, but they do not represent all Lithuanian mature organisations. Other research on CE has not been conducted in mature organisations. Neither has it used a similar approach to CE measuring. However, GEM results (Singer et al., 2014) show that Lithuania is in transition to innovation driven economy, thus organisations are expected to set innovations at the core of their activities as well as express CE highly. Therefore, the following hypothesis is suggested:

Hypothesis 1: CE is highly expressed in Lithuanian mature organisations.

According to Covin \& Slevin (1990), organisationallevel attributes, such as organisational structure and culture, do not make an organisation to be an entrepreneurial one because of their non-behavioural background. They also state that organisations are entrepreneurial because of their behaviour as it is the central and essential element of the entrepreneurial process. Innovations, strategic objectives and potential for growth are all related to organisational behaviour in regard to its current or future results.

\section{Institutional Factors of CE}

The characteristics frequently used in CE research, like innovativeness, proactiveness, autonomy, risk-taking and others, are not attributed to $\mathrm{CE}$ domain due to their origin of individuals rather than organisations even if they represent an organisation. Covin \& Lumpkin (2011) state that such elements as corporate culture and structure can be associated with CE, but do not define it. A set of features related to abilities, attitudes and tendencies to behave in a certain degree are previously described as entrepreneurial orientation (Lumpkin \& Dess, 1996), entrepreneurial corporate culture (Cornwall \& Perlman, 1990; Antoncic, 2001; Russell, 1999; McGuire, 2003) or entrepreneurial quality (Wang, 2008), but they are restructured in this paper into institutional factors of CE.

Recent attention of CE researchers (Urban, 2012; Van Doorn et al., 2013; Kuratko et al., 2014; Turro et al., 2014; Nason et al., 2015) to internal organisational environment reveals the importance of internal organisational settings for $\mathrm{CE}$ within the organisation. Institutional factors of $\mathrm{CE}$ represent three sets of internal organisational characteristics, particularly, managers' attitudes towards entrepreneurship, institutional support systems, and entrepreneurial culture.

Managers' attitudes towards entrepreneurship. Stevenson \& Jarillo Mossi (1990) argue that entrepreneurship within the organisation is dependent on the attitude of the individuals working there. Various researches (Kuratko et al., 1990; Zahra, 1991; Hornsby et al., 2002; Van Doorn et al., 2013; Kuratko et al., 2014) emphasise the importance of managers in all levels of organisation to its CE. Managers encourage their employees to undertake activities by supporting employees' initiatives, encouraging them to accept challenges and look for alternatives and better solutions, reflecting a positive attitude to employees' abilities to act (Kuratko et al., 1990; Kuratko et al., 2005), providing a certain set of freedom for employees and allowing the possibility to implement their ideas (Cornwall \& Perlman, 1990). Hornsby et al. (1993), Kuratko et al. (1990) include into manager's support such activities as delegation of decision making and freedom to select work methods, organise their own work and manage time, which reflects the employee empowerment for entrepreneurship.

Kuratko el al. (1990) argue that if a manager is tolerant to risk and provides a second opportunity after a failure, this will encourage employees to keep searching and developing. Sathe $(1985,1988)$ states that tolerance to failure can be acceptable only when employees learn from their previous mistakes. Tolerance to failure is also closely related to positive attitude towards risk. When an organisation explores innovations as a core of its activities, managers positively value employees' initiatives even when they are not sure of their success. Positively valued initiatives would correspond to positive value of employees who are taking the risk (Kuratko et al, 1990).

Support for small and experimental projects is suggested as another characteristic of managers by Kuratko et al. (1990) who discuss difficulties in fostering innovations in medium and large organisations and suggest implementing this type of projects as a possible solution. We have developed this feature into support of small and entrepreneurial projects providing the linkage to the result 
of entrepreneurial activity. Support might be provided in different ways, e.g. by devoting personal attention, sharing professional experience or recognizing the influence of such projects on the performance of the whole organisation.

The attitude of the manager towards entrepreneurship reflects the manager's opinion and his/her actual behaviour, which includes encouraging employees' initiatives and promoting employee empowerment as well as supporting small entrepreneurial projects and positive attitude towards risk. The development of theoretical model about the relationship of the manager with $\mathrm{CE}$ as well as other institutional factors of $\mathrm{CE}$ is not based on national or cultural context, so, we do not limit them to Lithuanian mature organisations only. However, the operationalisation of institutional characteristics and CE are different in other research studies and should be tested. Hence, the hypothesis is stated as follows:

Hypothesis 2a. Positive managers' attitudes toward entrepreneurship positively correlate with corporate entrepreneurship.

Institutional support systems. Morris et al. (2008) state that some organisations are more entrepreneurial than others. Moreover, Morris \& Kuratko (2002) argue that the reason of this is the organisational context. Continuous research (Sykes \& Block, 1989, Covin \& Slevin, 1991; Zahra, 1991; Russell \& Russell, 1992; Zahra \& Covin, 1995; Russell, 1999; Chen et al., 2005; Antoncic, 2007; Urban, 2012, Kuratko et al., 2014) confirms the importance of institutional support systems in CE. Institutional support systems represent managerial practices and are specified as the whole of formal regulations, systems and procedures applicable in the organisation. In the case of $\mathrm{CE}$, such important organisational characteristics as strategic control, organisational structure, corporate resources and reward system are distinguished.

Strategic control system for fostering CE is mainly designed for the identification of possible mistakes or gaps in the process. At the same time, it encourages organisations to think entrepreneurially (Sathe, 1988). Zhao (2005) states that the balance between freedom and control as well as flexible management systems are essential for R\&D and new product development. Moreover, control system is closely related to organisational structure. According to Kanter (1983), innovation friendly organisational structure needs to integrate the autonomy of departments/business units with a close cooperation between internal units of the structure. Chen et al. (2005) recognise the importance of the flat organisational structure in CE, while Russell \& Russell (1992) emphasise that the organic structure could foster innovations by providing possibilities to employees in cases of power, resources and information necessary for the development of new ideas.

Hornsby et al. (1999) and their continuous researches of CE (Kuratko et al., 2005; Kuratko et al., 2014) argue that organisation streaming in CE development and setting it as a strategic task, first of all faces the need of resources, their location and availability for entrepreneurial activities. Management of corporate resources is vital when it comes to the location of resources, their availability for new initiatives, the possibility to relocate them and the amount of time needed for this.
An additional factor of institutional support is related to employees' motivation. Kuratko et al. (1990) have found out that the reward system has to clearly define the goals and feedback, identify individual responsibility and include a reward for goals achieved in order to be effective in entrepreneurial organisation and foster entrepreneurial activities. Moreover, Kanter (1983) notes that the reward system has to be active, not merely declared. Further research of Kuratko et al. (2005) provide more principles of the reward system. The researchers claim that the reward system should be based on the employees' activities and provided for outstanding performance. The reward itself, according to Zwell (2000), might be and is desired to be not only a financial one. It is even more important to reward employees by acknowledging their input, providing possibilities for competence development, opportunities to be involved in desired activities and other forms of reward that would be valued by the employees.

Consequently, the third hypothesis is made:

Hypothesis 2b. Institutional support systems positively correlate with $C E$.

Entrepreneurial culture. In some previous researches, (Russell \& Russell, 1992; Cornwall \& Perlman, 1990) an assumption was made that an entrepreneurial organisation revealed a specific organisational culture. Several types of entrepreneurial culture with one or several aspects related to entrepreneurship were identified: innovation culture (Oden, 1997; Jamrog, Vickers \& Bear, 2006), change culture (Patterson \& Rolheiser, 2004; Gilley, 2005), and culture of competence (Zwell, 2000). Researches of entrepreneurial culture are made in organisational and national levels, both of them revealing the importance of culture for $\mathrm{CE}$ and innovations (Russel, 1990; Antoncic \& Hisrich, 2001; Dimitratos et al., 2012; Urban, 2012; Turro et al., 2014). Some researchers (Russell, 1990; Cornwall \& Perlman, 1990; McGuire, 2003) present and analyse entrepreneurial organisational culture specifically.

Entrepreneurial culture has been operationalised on the basis of analysis of organisational culture as a factor of CE. Such values supporting $\mathrm{CE}$ as innovativeness, proactiveness, risk-taking, open communication, cooperation and openness used to be analysed as a single feature and interpreted separately (Deal \& Kennedy, 1982; Handy, 1985; Cooke \& Lafferty, 1987; Denison, 1990; Cornwall \& Perlman, 1990; Cameron \& Quinn, 1999; Russell, 1999; Antoncic, 2001; McGuire, 2003). However, today they are attributable to the entrepreneurial culture phenomena.

Although according to McGuire (2003), innovativeness and proactiveness might be joined together with proactive innovativeness, we do separate them into two different features due to the existing differences between them. They are researched as separate features in the research carried out by Miller (1983), later on by Ginsberg (1985), Covin \& Slevin (1989) and others. Lumpkin \& Dess (1996) state that innovativeness reveals a tendency of an organisation to engage in and support new ideas and creative processes. In case of corporate culture, it reflects corporate values, believes and norms of the core tendency to step further from the existing practices and technologies and act in an innovative way. Proactiveness is related to future activities. 
McGuire (2003) describes the market creation function here. Proactiveness as a feature of entrepreneurial culture represents willingness to use opportunities provided by continuous scanning of the internal and external organisational environment. Any situation or change in it, according to Cornwall \& Perlman (1990), is a possibility to behave entrepreneurially.

Risk taking as a feature of corporate culture is closely related to individual risk-taking propensity. It might be absolutely unacceptable for certain individuals to take a risk, while others might continuously search for activities with uncertain success (not having all information), i.e. activities with uncertainty (Kuratko et al., 1990; Cornwall \& Perlman, 1990). Among other features of entrepreneurial culture, Russell (1999) identifies cultural norms that promote tolerance for failure. General tolerance of failure is necessary for shared value of risk taking within an organisation.

Entrepreneurial culture incorporates open communication as corporate value of the core in all organisational activities (Peters \& Waterman, 1982; Zahra 1991, Antoncic \& Hisrich, 2001; McGuire, 2003). According to Cornwall \& Perlman (1990), effective communication consists of listening, purifying information until it becomes useful for particular activities, dissemination and implementation. Moreover, both formal and informal forms of communication are valuable for CE (Pinchot, 1995). General openness (or "voice", according to McGuire, 2003) also contributes to $\mathrm{CE}$ as a feature of entrepreneurial culture together with the feature of open communication. It reflects both formal and tangible possibility to reveal your own opinion and knowing that it will be audible in the organisation. According to McGuire (2003), a possibility to present a negative opinion within the organisation in regard to any organisational question is essential as it provides the opportunity to improve the organisation itself as well as its processes and products. Russell (1999) notes that norms of entrepreneurial culture related to openness encourage openminded considerations when generating new ideas or projects.

According to Kanter (1983), Stopford \& Baden-Fuller (1994), teamwork or team-orientation is especially valuable for the development of CE. In the case of teamwork, cooperation plays the main role for the development of ideas. Cooperation is necessary in all levels of organisational structure for ensuring the development, dissemination and implementation of innovations. As a feature of entrepreneurial culture, cooperation develops an appropriate environment for new ideas.

The results of the research by Zahra (1991) and Antoncic \& Hisrich (2001) confirm a positive relation between corporate values and CE. Zahra (1991) and Antoncic \& Hisrich (2001) have researched corporate values in regard to their articulation (clear or not), while Russell \& Russell (1992) have found a positive correlation between innovation-related norms and a successful entrepreneurial strategy. McGuire (2003) has developed a similar set of six factors or characteristics of entrepreneurial culture and confirmed their relations with CE. However, current dimensionalisation of corporate culture differs in cases of proactiveness, innovativeness and risk taking. Thus, the hypothesis is as follows:

\section{Hypothesis 2c. Entrepreneurial culture positively correlates with $C E$.}

We finalise the discussion on institutional factors of CE with the hypothesis about the impact of institutional factors on CE. Of course, the impact is possible to discuss only if the correlation exists ( $\mathrm{H} \mathrm{2a-c).} \mathrm{However,} \mathrm{the} \mathrm{discussion}$ about their influence on CE continuously appears in research literature (Kuratko et al., 1990; Zahra, 1991; Russell \& Russell, 1992; Antoncic, 2001; Hornsby et al., 2002; Kuratko et al., 2005). Moreover, Chung \& Gibbons (1997) state that CE might be developed and controlled only by an appropriate corporate culture; Morris \& Kuratko (2002) emphasise the importance of institutional support systems to CE; and Kuratko et al. (1990) argue similarly about the manager's influence. Thus, the following hypothesis is made:

Hypothesis 2. CE is influenced by managers' attitudes toward entrepreneurship, institutional support systems and entrepreneurial culture.

The hypotheses of the present research are presented in the theoretical model of CE and its factors in Figure 1.

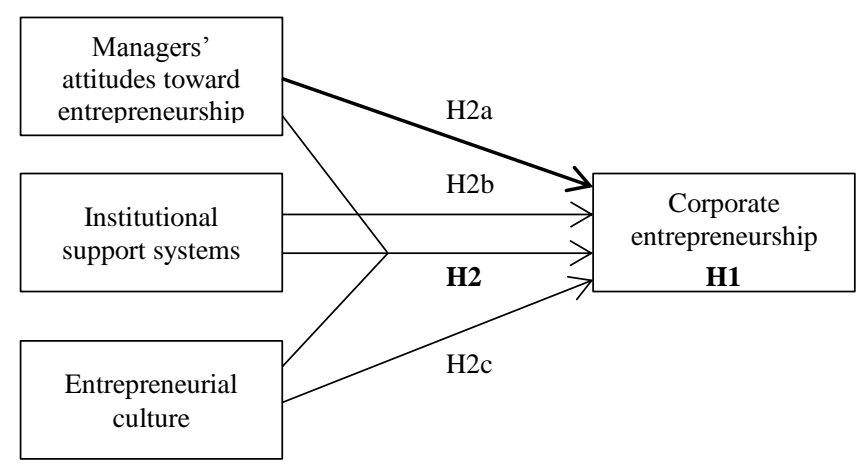

Figure 1. Theoretical Model of CE and its Institutional Factors

\section{Research Methodology}

The quantitative empirical research of Lithuanian mature organisations was selected for testing the hypotheses and exploring the theoretical model of $\mathrm{CE}$ and its factors empirically. Online survey was fully completed by 173 managers from 76 Lithuanian mature organisations that were randomly selected from the general population of 712 Lithuanian mature organisations with 100 and more employees. Therefore, the results are valid for such organisations in the whole country.

Regarding other characteristics of the sample, the size of middle or large is necessary for institutional settings within the organisations, therefore, the lowest count of employees was set at 100 due to have functioning institutional settings. The maturity is related to the age of an organisation and in the case of this research it was 10 or more years. It mostly depends on the historical background of Lithuanian business market but it also corresponds to the years of maturity beginning in other research of organisational life-cycle (Pundziene et al., 2006). Other criteria used are the rates of employee turnover and financial turnover of the last three years (each less than $15 \%$, according Lester et al. 2003). 
The first stage of the research consisted of an invitation letter by email to CEOs of selected organisations and a few short questions regarding their status in order to ensure the maturity of these companies. Information about organisation, like its size, age, sector, and location, has been collected together with their agreement to participate in the survey. Necessary sampling size of organisations was 61, calculated according to Bartlett et al. (2001). 92 organisations were randomly selected, representing their distribution in the regions, and 85 of them agreed to participate. Final number of participating organizations reduced to 76 due to two main reasons: no confirmation of maturity or later decline because of work overload. Return rate in case of organisations was high $(82.6 \%)$, however, it was reached due to continuous communication with organisations by email and calls, arguing the meaning of participation each selected organisation. Therefore, sample method, size and distribution according the regions ensure generalisability of research results to mature organisations of the whole country.

The second stage consisted of a detailed quantitative online survey using the main questionnaire about $\mathrm{CE}$ and its factors. Return rate in case of respondents is unknown as there is no information how many employees have actually been asked to participate in this survey. Organisations were encourage to involve at least 3 managers from various positions, but final numbers of respondents within each organisation vary from 1 to 17 (average 2.21). Respondents were asked to provide information about their gender, age, position, and total tenure in the researched organisation (see Table 1).

Table 1

Sample Characteristics in the Level of Respondents

\begin{tabular}{|c|c|c|c|}
\hline & Category & Frequency & Percentage \\
\hline \multirow{3}{*}{ Gender } & Male & 75 & 43.3 \\
\hline & Female & 93 & 53.8 \\
\hline & $\mathrm{n} / \mathrm{a}$ & 5 & 2.9 \\
\hline \multirow{6}{*}{$\begin{array}{l}\text { Age } \\
\text { (years) }\end{array}$} & $<25$ & 10 & 5.8 \\
\hline & $25-35$ & 38 & 22.0 \\
\hline & $36-45$ & 77 & 44.5 \\
\hline & $46-55$ & 25 & 14.4 \\
\hline & $>55$ & 17 & 9.80 \\
\hline & $\mathrm{n} / \mathrm{a}$ & 6 & 3.5 \\
\hline \multirow{4}{*}{$\begin{array}{l}\text { Level of } \\
\text { managerial } \\
\text { position }\end{array}$} & Top & 45 & 26.0 \\
\hline & Middle & 65 & 37.6 \\
\hline & Lower & 58 & 33.5 \\
\hline & $\mathrm{n} / \mathrm{a}$ & 5 & 2.9 \\
\hline \multirow{6}{*}{$\begin{array}{l}\text { Job tenure } \\
\text { (years) }\end{array}$} & $<1$ & 12 & 6.9 \\
\hline & $1-3$ & 23 & 13.3 \\
\hline & $4-7$ & 69 & 39.9 \\
\hline & $8-14$ & 32 & 18.5 \\
\hline & $>15$ & 31 & 17.9 \\
\hline & $\mathrm{n} / \mathrm{a}$ & 6 & 3.5 \\
\hline
\end{tabular}

The main questionnaire was developed by Duobiene (2013; 2014). It is constructed in the line of the theoretical model and represents its characteristics (see Table 2).

Table 2

Description of the Questionnaire

\begin{tabular}{|c|c|c|c|c|}
\hline Scale & $\begin{array}{c}\text { No. } \\
\text { of } \\
\text { items }\end{array}$ & $\begin{array}{l}\text { Reliability of } \\
\text { scale, } \\
\text { Cronbach's } \\
\alpha\end{array}$ & $\begin{array}{l}\text { Factors' extraction } \\
\text { sums of squared } \\
\text { loading, } \%\end{array}$ & References \\
\hline Corporate entrepreneurship & 21 & 0.923 & 64.66 & $\begin{array}{l}\text { Schollhammer, (1982); Vesper, (1984); Venkatram } \\
\text { (1989); Lumpkin \& Dess (1996); Zahra, (1996); Covin \& } \\
\text { Miles (1999); Sharma \& Chrisman, (1999); Russell } \\
\text { (1999); Antoncic \& Hisrich (2001), Wickham (2004); } \\
\text { Chen et al. (2005); Antoncic (2007); Ling et al. (2008) }\end{array}$ \\
\hline $\begin{array}{c}\text { Manager's attitudes towards } \\
\text { entrepreneurship }\end{array}$ & 25 & 0.994 & 79.46 & $\begin{array}{l}\text { Sathe (1988), Kuratko et al. (1990); Hornsby et al. (1993); } \\
\text { Stopford \& Baden-Fuller (1994); Dougherty \& Hardy } \\
\text { (1996); Zwell (2000); Hornsby et al. (2002); Kuratko et } \\
\text { al. (2005); Lumpkin } \text { et al. (2009) }\end{array}$ \\
\hline Institutional support systems & 20 & 0.914 & 66.12 & $\begin{array}{l}\text { Miller \& Friesen (1982); Kanter (1983); Sathe (1988); } \\
\text { Cornwall \& Perlman (1990); Kuratko et al. (1990); Zwell } \\
\text { (2000); Hornsby et al. (2002); Chen et al. (2005); Kuratko } \\
\text { et al. (2005); Lumpkin et al. (2009) }\end{array}$ \\
\hline Entrepreneurial culture & 36 & 0.953 & 70.63 & Kanter (1983); Russell \& Russell (1992); McGuire (2003) \\
\hline
\end{tabular}

Each scale consists of a set of subscales corresponding to the theoretical model. Each subscale includes 3-8 items which have to be evaluated by 7-points Likert scale.

Main variables are calculated and represent means of sub-scales values. Running regression analysis additional variables are calculated in the same way due to high multicollinearity of institutional factors. The data are analysed using the SPSS 20 software for descriptive statistics, correlation and regression analyses.

\section{Results}

The expression of $\mathrm{CE}$ in Lithuanian mature organisations. The results of the present research have shown that the expression of CE in Lithuanian mature organisations is higher than the average of scale, so the first hypothesis has been confirmed (one sample test value $=4$, $\mathrm{t}=4.364, \mathrm{df}=75, \mathrm{p}<0.01)$. 
Results on CE in Lithuanian Mature Organisations

\begin{tabular}{rcccc}
\hline & Minimum & Maximum & Mean & $\begin{array}{c}\text { Std. } \\
\text { Deviation }\end{array}$ \\
\hline CE & 1.42 & 6.44 & 4.51 & 1.01 \\
\hline $\begin{array}{r}\text { Strategic } \\
\text { objectives }\end{array}$ & 1.38 & 6.75 & 4.58 & 1.17 \\
\hline Innovations & 1.38 & 6.13 & 3.92 & 1.13 \\
\hline $\begin{array}{r}\text { Potential for } \\
\text { growth }\end{array}$ & 1.50 & 7.00 & 5.08 & 1.15 \\
\hline
\end{tabular}

The results on CE characteristics differ significantly between characteristics. The difference between innovations and potential for growth is the highest one (paired sample test $\mathrm{t}=-10.200, \mathrm{df}=75, \mathrm{p}<0.01$ ) and the difference between potential for growth and strategic objectives is the lowest one $(\mathrm{t}=5.721, \mathrm{df}=75, \mathrm{p}<0.01)$. Lithuanian mature organisations have a great potential of growth (see Table 3) while they are not aiming at such amount, for example, strategic objectives are scored lower than the potential of growth. Regarding the evaluation of potential for growth, only one item about the research for the development of new products is evaluated less than 4 points (3.78), but the mean of total potential for growth is much higher than the scale average.

However, the attention must be paid to the innovations, and they are scored at the lowest level in regard to other characteristics of CE. The main reason of such evaluation is the lack of radical innovations, sticking to the same business and not looking for new opportunities. The results support the findings of Miller and Friesen (1984) about the lowest level of radical innovations in mature organisations. The results on single items have also disclosed the lack of financial investments in order to implement innovations, however, investments made by organisation were not investigated.

Institutional factors of $\mathrm{CE}$ in Lithuanian mature organisations. Three institutional factors were measured in the research: institutional support systems, entrepreneurial culture, and manager's attitudes towards entrepreneurship.

The results on institutional support systems (see Table 4) have shown that Lithuanian mature organisations have these systems appropriate for $\mathrm{CE}$ (one sample test value $=4$, $\mathrm{t}=4.073, \mathrm{df}=75, \mathrm{p}<0.01)$. Only organisational structure and reward system is scored similarly, while strategic control system has a significantly higher score. In general, the difference between strategic control system and corporate resources is the highest one (paired sample test $t=7.057$, $\mathrm{df}=75, \mathrm{p}<0.01$ ) and the lowest significant difference in this set of variables is between corporate resources and reward system $(\mathrm{t}=-2.024, \mathrm{df}=75, \mathrm{p}<0.05)$.

A low score of corporate resources within Lithuanian mature organisation are mainly reasoned by a very limited possibility to get internal resources for financing employees' innovative projects or ideas and the lack of time available for the explication of the primary idea.
Results on Institutional Support Systems in Lithuanian Mature Organisations

\begin{tabular}{rcccc}
\hline & Minimum & Maximum & Mean & $\begin{array}{c}\text { Std. } \\
\text { Deviation }\end{array}$ \\
\hline $\begin{array}{r}\text { Institutional } \\
\text { support systems }\end{array}$ & 1.85 & 6.33 & 4.41 & 0.89 \\
\hline $\begin{array}{r}\text { Strategic control } \\
\text { system }\end{array}$ & 2.00 & 6.50 & 4.88 & 0.89 \\
\hline $\begin{array}{r}\text { Corporate } \\
\text { resources }\end{array}$ & 1.00 & 6.40 & 4.04 & 1.23 \\
\hline $\begin{array}{r}\text { Organisational } \\
\text { structure }\end{array}$ & 1.80 & 7.00 & 4.40 & 1.10 \\
\hline Reward system & 1.00 & 7.00 & 4.34 & 1.22 \\
\hline
\end{tabular}

The results on organisational structure have revealed an unexplored possibility of cooperation between different departments. The reward systems in Lithuanian mature organisations are formalised and usually do not provide the possibility to award employees who successfully implemented ideas significant for organisational performance. Even strategic control system is scored higher. Means of single items in this subscale has shown that strategic control system in Lithuanian mature organisations is usually based on formal and inflexible practices instead of just ensuring the implementation of strategic objectives.

The results on entrepreneurial culture have shown that organisational culture in Lithuanian mature organisations is entrepreneurial one (one sample test value $=4, \mathrm{t}=6,677, \mathrm{df}=75$, $\mathrm{p}<0.01)$. Entrepreneurial culture includes expressed characteristics of innovativeness, proactiveness, risk taking, open communication, cooperation and openness (see Table $5)$.

Table 5

Results on Entrepreneurial Culture in Lithuanian Mature Organisations

\begin{tabular}{rcccc}
\hline & Minimum & Maximum & Mean & $\begin{array}{c}\text { Std. } \\
\text { Deviation }\end{array}$ \\
\hline $\begin{array}{r}\text { Entrepreneurial } \\
\text { culture }\end{array}$ & 2.05 & 6.49 & 4.67 & 0.87 \\
\hline $\begin{array}{r}\text { Innovativeness } \\
\text { Proactiveness }\end{array}$ & 1.60 & 7.00 & 4.89 & 0.95 \\
\hline Risk taking & 1.00 & 6.67 & 4.55 & 1.05 \\
\hline $\begin{array}{r}\text { Open } \\
\text { communication }\end{array}$ & 2.47 & 7.00 & 5.08 & 1.15 \\
\hline Cooperation & 2.25 & 7.00 & 5.05 & 1.00 \\
\hline Openness & 1.60 & 6.40 & 4.37 & 1.11 \\
\hline
\end{tabular}

Similar scores are among innovativeness, open communication and cooperation as well as proactiveness and openness, while others differ significantly. The difference between risk taking and open communication is the highest one (paired sample test $\mathrm{t}=-7.272, \mathrm{df}=75, \mathrm{p}<0.01$ ) and the lowest significant difference is between risk taking and open communication ( $\mathrm{t}=-2.497, \mathrm{df}=75, \mathrm{p}<0.05)$.

The least common feature of entrepreneurial culture in Lithuanian mature organisations is risk taking. Even if the mean of risk taking is still higher than a scale mean, only two items out of six were evaluated higher. Both of them are related to the possibility of giving a second chance. Lithuanian mature organisations value employees who 
generate and implement their ideas. Moreover, colleagues from different departments cooperate with each other and share ideas in order to achieve successful final results.

Managers' attitudes toward entrepreneurship are scored at the highest level among all three researched factors of CE in Lithuanian mature organisations and it is also under the scale average (one sample test value $=4, \mathrm{t}=5.917, \mathrm{df}=75$, $\mathrm{p}<0.01)$.

The results allow to distinguish three groups of characteristics (see Table 6) as differences between variables of different groups are significant (paired sample test $\mathrm{t}=-3.987$ and $\mathrm{t}=>2.854$, when $\mathrm{p}<0.01, \mathrm{df}=75$ ). Encouragement to take activity and tolerance of failure is scored higher and fall into the first group; the second group consists of employees' engagement and support to small entrepreneurial projects and is score lower; and the lowest score goes to positive attitude toward risking as the third group.

Table 6

Results on Managers' Attitudes Toward Entrepreneurship in Lithuanian Mature Organisations

\begin{tabular}{|c|c|c|c|c|}
\hline & Minimum & Maximum & Mean & $\begin{array}{c}\text { Std. } \\
\text { Deviation }\end{array}$ \\
\hline $\begin{array}{r}\text { Manager's } \\
\text { attitudes toward } \\
\text { entrepreneurship }\end{array}$ & 1.88 & 6.85 & 4.73 & 1.07 \\
\hline $\begin{array}{r}\text { Encouragement to } \\
\text { take activity }\end{array}$ & 1.80 & 7.00 & 4.97 & 1.25 \\
\hline $\begin{array}{r}\text { Employees' } \\
\text { empowerment }\end{array}$ & 1.80 & 7.00 & 4.67 & 1.21 \\
\hline Tolerance to failure & 2.40 & 7.00 & 5.14 & 1.09 \\
\hline $\begin{array}{r}\text { Support of small } \\
\text { and entrepreneurial } \\
\text { projects }\end{array}$ & 1.00 & 7.00 & 4.62 & 1.27 \\
\hline $\begin{array}{r}\text { Positive attitude } \\
\text { towards risk }\end{array}$ & 1.00 & 7.00 & 4.27 & 1.45 \\
\hline
\end{tabular}

The results on single items have shown that managers of Lithuanian mature organisations encourage their employees to implement new ideas and are positive regarding their potential to be successful in this. In case of failure, managers are tolerant and willing to find out the reasons (in order to avoid this in the future, but not for the punishment), threating failure as a learning opportunity. Managers have a clear understanding that it is impossible to do all activities successfully without any exceptions. However, managers are not really positive towards risking and tend to be cautious in encouraging their employees to take up such activities. They encourage their employees to estimate the risk of new ideas carefully, but they do not appreciate high risk.

The evaluation of employees' engagement in small entrepreneurial projects has revealed the possibilities to develop more positive attitudes in this group of characteristics. The lowest scored items are related to the delegation of the responsibilities to the best workers, freedom to manage their time or implement improvements that would lead to better performance. Managers are already providing freedom to choose work methods and make decisions in everyday tasks, but they are still sceptical about small entrepreneurial projects. Lithuanian mature organisations still lack positive attitudes of the managers in this area.
The relations between $\mathrm{CE}$ and its factors in Lithuanian mature organisations. The results have indicated that all three factors of CE in Lithuanian mature organisations are strongly positively correlated and their relation to $\mathrm{CE}$ is also positive (see Table 7) that confirm $\mathrm{H} 2 \mathrm{a}, \mathrm{H} 2 \mathrm{~b}$ and $\mathrm{H} 2 \mathrm{c}$.

Table 7

Correlations between Main Variables

\begin{tabular}{lllll}
\hline & & CE & $\begin{array}{c}\text { Institutio } \\
\text { nal } \\
\text { support } \\
\text { systems }\end{array}$ & $\begin{array}{c}\text { Entrep } \\
\text { re- } \\
\text { neurial } \\
\text { culture }\end{array}$ \\
\hline $\begin{array}{l}\text { Institutional } \\
\text { support systems }\end{array}$ & $\begin{array}{l}\text { Spearman's } \\
\text { rho }\end{array}$ & $0.556^{* *}$ & & \\
\cline { 2 - 5 } & Sig. & 0.000 & & \\
\hline $\begin{array}{l}\text { Entrepreneurial } \\
\text { culture }\end{array}$ & $\begin{array}{l}\text { Spearman's } \\
\text { rho }\end{array}$ & $0.542^{* *}$ & $0.853^{* *}$ & \\
\cline { 2 - 5 } $\begin{array}{l}\text { Manager's } \\
\text { attitudes toward } \\
\text { entrepreneurship }\end{array}$ & $\begin{array}{l}\text { Spearman's } \\
\text { rho }\end{array}$ & $0.369^{* *}$ & $0.697^{* *}$ & $0.822^{* *}$ \\
\cline { 2 - 5 } **. Correlation is significant at the 0.01 level (2-tailed). & 0.0000 \\
\hline
\end{tabular}

However, the power of relationship differs. The correlation between CE and entrepreneurial culture as well as institutional support systems is moderately strong, but the correlation between managers' attitudes toward entrepreneurship is week.

The difference between powers of correlation suggests a preposition that managers' attitudes toward entrepreneurship and entrepreneurial culture with institutional support systems are related differently with CE. Therefore, the regression analysis was used further and applied in two steps: (1) on testing the influence of the manager's attitude towards entrepreneurship on entrepreneurial culture and institutional support systems and (2) on testing the influence of entrepreneurial culture and institutional support systems on CE. The results are presented in Figure 2.

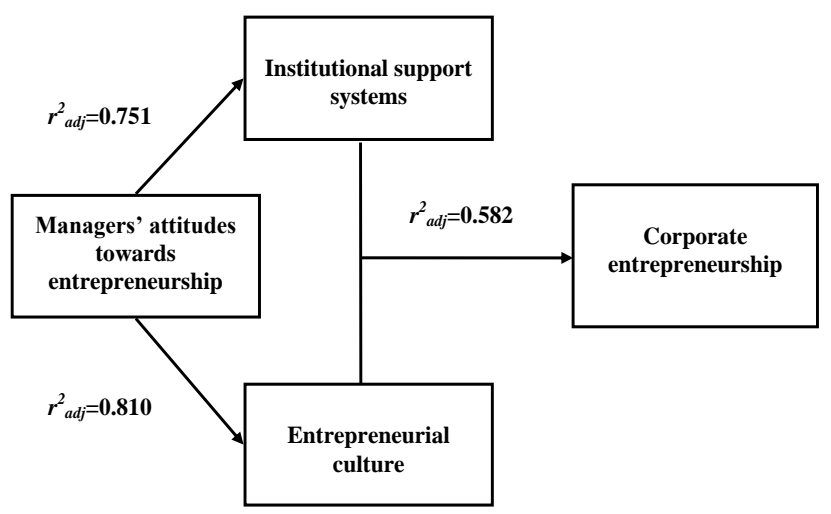

Figure 2. Results on Influence of Institutional Factors on CE

The results of regression analysis (ANOVA) show that positive managers' attitudes toward entrepreneurship have a high impact on support systems in their institution $(\mathrm{F}=163,643, \mathrm{df}=1, \mathrm{p}<0.01)$ and even higher impact on entrepreneurial culture there $(\mathrm{F}=231,035, \mathrm{df}=1, \mathrm{p}<0.01)$. Later on, the entrepreneurial culture and institutional support systems together (using mean of both variables) 
make a positive impact to the corporate entrepreneurship in that organisation $(\mathrm{F}=75.051, \mathrm{df}=1, \mathrm{p}<0.01)$. Thus, the last hypothesis has been confirmed. The model of influence (Fig. 2) of institutional factors on $\mathrm{CE}$ explains the expression of $\mathrm{CE}$ in Lithuanian mature organisations.

\section{Discussion and Conclusions}

The paper presents the results of quantitative research of CE, based on Wickham's (2004) concept that includes innovations, strategic objectives and potential for growth. Characteristics like innovativeness, proactiveness, autonomy, risk-taking and others, are not attributed to the CE model in this research due to their origin of individuals rather than organisations, but they are restructured into institutional factors of CE: managers' attitude toward entrepreneurship, institutional support systems and entrepreneurial culture.

The research results have shown that $\mathrm{CE}$ in Lithuanian mature organisations is high. Innovations in Lithuanian mature organisations are scored lower than strategic objectives and potential for growth mainly because of the lack of radical innovations, being too much stuck to same business, therefore, not looking for new opportunities. Innovations are the $\mathrm{CE}$ characteristic that should be elaborated in Lithuanian mature organisations, especially as the results on institutional support systems have shown existing untapped potential of the usage of corporate resources.

Corporate resources within Lithuanian mature organisation are mainly reasoned by a very limited possibility to get internal resources for financing employees' innovative projects or ideas and the lack of time available for the explication of the primary idea. The importance of corporate resources availability to $\mathrm{CE}$ in case of time availability has been confirmed also in emerging economies (Bhardwaj \& Sushil, 2012). Moreover, organisations might need additional actions. Covin and
Lumpkin (2011) note that due to use external opportunities organisations might have to reconfigure their resources.

The research results have also confirmed the importance of entrepreneurial culture to $\mathrm{CE}$ and it is described by a specific set of values, used in previous researches (Kanter, 1983; Russell \& Russell, 1992; McGuire, 2003; Van Doorn et al., 2013). The key to CE expression in Lithuanian mature organisations displays entrepreneurial spirit in corporate culture of innovativeness, open communication, cooperation, and especially proactiveness and openness. However, the last feature of entrepreneurial culture - risk taking - is not so common in Lithuanian mature organisations. Mainly, they miss the existence of second chance as well as the cultural value.

According to the results, positive managers' attitudes are essential for the development of CE. The role and importance of managers from top to operational levels has been recognizes in many previous research (Hornsby et al., 2002; Kuratko et al., 2005; Gilley, 200; Ling et al., 2008; Van Doorn et al., 2013), but current results reveal its nature. Managers' attitudes toward entrepreneurship correlate with $\mathrm{CE}$, but their correlation is weak as well as they impact $\mathrm{CE}$ less than two other institutional factors. Thus, they impact CE via institutional support systems and entrepreneurial culture. The relationship between institutional factors and their impact on CE provide the guidelines for Lithuanian mature organisations for fostering $\mathrm{CE}$ through rethinking and directly changing institutional support systems and/or corporate culture, or including the change of managers' attitudes toward entrepreneurship into the process of $\mathrm{CE}$ development.

The current research is limited to one country, however, it has confirmed the importance of institutional support systems for CE, contributing to the knowledge about CE and $\mathrm{CE}$ in mature organisations. Moreover, the research results on managers' contribution to entrepreneurial culture and institutional support systems and their impact to $\mathrm{CE}$ provides the understanding of $\mathrm{CE}$ in mature organisations.

\section{References}

Andriuscenka, J. (2003). Strategic Entrepreneurship: Conceptual Attitude in Management Paradigm. Organizaciju vadyba: sisteminiai tyrimai: mokslo darbai, 26, 7-25.

Andriuscenka, J., \& Adamoniene, R. (2006). The study of methodology of strategic management appliance for the small-scale entrepreneurship. Business and Management 2006: The 4th international scientific conference selected papers, $223-230$.

Antoncic, B. (2007). Intrapreneurship: a comparative structural equation modelling study. Industrial Management \& Data Systems, 107(3), 309-325. https://doi.org/10.1108/02635570710734244

Antoncic, B., \& Hisrich, R. D. (2001). Intrapreneurship: construct refinement and cross-cultural validation. Journal of Business Venturing, 16, 495-527. https://doi.org/10.1016/S0883-9026(99)00054-3

Antoncic, B. (2001). Organizational processes in intrapreneurship: a conceptual integration. Journal of Enterprising Culture, 9(2), 221-236. https://doi.org/10.1142/S0218495801000122

Antoncic, B., \& Hisrich, R.D. (2004). Corporate entrepreneurship contingencies and organizational wealth creation. Journal of Management Development, 23(6), 518-550. https://doi.org/10.1108/02621710410541114

Barringer, M. W., \& Milkovich, A. G. (1998). A Theoretical Exploration of the Adoption and Design of Flexible Benefit Plans: A Case of Human Resource Innovation. Academy of Management Review, 23(2), 305-324.

Bartkus, E. (2004). Smulkus verslas ir uZimtumo problemos Lietuvoje. Ekonomika ir vadyba, 1(7), 16-20.

Beer, M., Eisenstat, R. A., \& Spector, B. (1990). The critical path to corporate renewal. Cambridge: Harvard Business School Press.

Bharwaj, B. R., \& Sushil. (2012). Internal environment for corporate entrepreneurship: Assessing CEAI model for emerging economies. Journal of Chinese Entrepreneurship, 4(1), 70-87. https://doi.org/10.1108/17561391211200948 
Boekema, F., Morgan, K., Bakkers, S., \& Ruttan, R. (eds) (2000). Knowledge, innovation and economic growth: The theory and practice of learning regions. Edward Elgar, Cheltenham.

Braynt, S. (1997). Strategic management: Developing and realizing a strategic vision. Public Management, 79(10), $28-33$.

Cameron, K. S., \& Quinn, R. E. (1999). Diagnosing and Changing Organizational Culture. NY: Addison-Wesley Inc.

Chen, J., Zhu, Z., \& Anquan, W. (2005). A system model of corporate entrepreneurship. International Journal of Manpower, 26(6), 529-543. https://doi.org/10.1108/01437720510625449

Chung, L. H., \& Gibbons, P. T. (1997). Corporate entrepreneurship: The roles of ideology and social capital. Group and Organizational Management, 22(1), 10-30. https://doi.org/10.1177/1059601197221004

Cooke, R. A., \& Lafferty, J. C. (1987). The Organizational Culture Inventory. Plymouth: Human Synergistics, Inc.

Cornwall, J. R., \& Perlman, B. (1990). Organizational entrepreneurship. Homewood, IL: Boston-Irvin.

Covin, J. G., \& Lumpkin, G. T. (2011). Entrepreneurial Orientation Theory and Research: Reflections on a Needed Construct. Entrepreneurship Theory and Practice, 35(5), 855-872. https://doi.org/10.1111/j.1540-6520.2011.00482.x

Covin, J. G., \& Miles, M. P. (1999). Corporate entrepreneurship and the pursuit of competitive advantage. Entrepreneurship Theory and Practice, 23, 47-63.

Covin, J. G., \& Slevin, D. P. (1989). The strategic management of small firms in a postile and benign environments. Strategic Management Journal, 10(1), 75-87. https://doi.org/10.1002/smj.4250100107

Covin, J. G., \& Slevin, D. P. (1990). New venture strategic posture, structure and performance: An industry life cycle analysis. Journal of Business Venturing, 5(2), 123-135. https://doi.org/10.1016/0883-9026(90)90004-D

Covin, J. G., \& Slevin, D. P. (1991). A conceptual model of entrepreneurship as firm behavior. Entrepreneurship Theory and Practice, 16(1), 7-25.

Covin, J. G., \& Wales, W. J. (2011). The Measurement of Entrepreneurial Orientation. Entrepreneurship Theory and Practice, 34(4), 677-702.

De la Mothe, J., \& Paquet, G. (1998). National innovation systems, 'real economies' and instituted processes. Small Business Economics, 11, 101-111. https://doi.org/10.1023/A:1007949811411

Deal, T. E., \& Kenedy, A. A. (1982). Corporate cultures: The rites and rituals of corporate life. MA: Addison-Wesley Publishing Co.

Denison, D. (1990). Corporate Culture and Organizational Effectiveness. NY: John Wiley.

Dimitratos, P., Voudouris, I., Plakoyiannaki, E., \& Nakos, G. (2012). International entrepreneurial culture - toward a comprehensive opportunity-based operationalization of international ntrepreneurship. International Business Review, 21, 708-721. https://doi.org/10.1016/j.ibusrev.2011.08.001

Dougherty, D., \& Hardy, C. (1996). Sustained product innovation in large, mature organizations: Overcoming innovationto-organization problems. Academy of Management Journal, 39, 1120-1153. https://doi.org/10.2307/256994

Duobiene, J. (2013). Corporate entrepreneurship in organisational life-cycle. Economics and management = Ekonomika ir vadyba, 18(3), 584-595. https://doi.org/10.5755/j01.em.18.3.5027

Duobiene, J. (2014). Organizacines verslininkystes vertinimo instrumentas. Management Theory and Studies for Rural Business and Infrastructure Development, 36(1), 45-55. https://doi.org/10.15544/mts.2014.005

Gilley, A. (2005). The manager as change leader. Westport, CT: Praeger.

Ginsberg, A. (1985). Measuring changes in entrepreneurial orientation following industry deregulation: The development of a diagnostic instrument. Proceedings of the International Council of Small Business, 50-57.

Greblikaite, J., \& Krisciunas, K. (2012). Does Competence-Oriented Higher Education Lead to Students' Competitiveness? Inzinerine Ekonomika-Engineering Economics, 4(54), 20-26.

Gronskas, V. (2000). Prekines verslininkystes ekonominis turinys. Inzinerine Ekonomika-Engineering Economics, 3(18), $21-31$

Grundey, D., \& Sarvutyte, M. (2007). Women enterepreneurship in the European labour market: time to go online. Transformations in Business \& Economics, 6(2), suppl. A, 197-218.

Guth, W., \& Ginsburg, A. (1990). Guest editorial introduction: corporate entrepreneurship. Strategic Management Journal, $11,5-15$.

Handy, C. B. (1985). Understanding Organizations. Harmondsworth: Penguin Books.

Hornsby, J. S., Kuratko, D. F., \& Zahra, S. A. (2002). Middle managers' perception of the internal environment for corporate entrepreneurship: assessing a measurement scale. Journal of Business Venturing, 17, $253-73$. https://doi.org/10.1016/S0883-9026(00)00059-8

Hornsby, J. S., Naffziger, D., Kuratko D. F., \& Montagno, R. V. (1993). An interactive model of the corporate entrepreneurship process. Entrepreneurship Theory and Practice, 17(2), 29-37. 
Hornsby, J. S., Kuratko D. F., \& Montagno, R. V. (1999). Perception of Internal Factors for Corporate Entrepreneurship: A Comparison of Canadian and U.S. Managers. Entrepreneurship Theory and Practice, 24(2), 9-24.

Ireland, R. D., Covin, J. G., \& Kuratko, D. F. (2009). Conceptualizing Corporate Entrepreneurship Strategy. Entrepreneurship Theory and Practice, 33(1), 19-46. https://doi.org/10.1111/j.1540-6520.2008.00279.x

Jamrog, J., Vickers, M., \& Bear, D. (2006). Building and sustaining a culture that supports innovations. Human Resource Planning, 29(3), 9-19.

Jucevicius, R. (1998). Strateginis organizaciju vystymas. Kaunas: Pasaulio lietuviu kulturos, mokslo ir svietimo centras.

Kanter, R.M. (1985). Supporting innovation and venture development in established companies. Journal of Business Venturing, 1(1), 47-60. https://doi.org/10.1016/0883-9026(85)90006-0

Krisciunas, K., \& Cepkauskiene, J. (2004). Penetration of Entrepreneurship in Lithuanian Economy. Inzinerine EkonomikaEngineering Economics(4), 45-53.

Krisciunas, K., \& Greblikaite, J. (2007). Entrepreneurship in Sustainable Development: SMEs Innovativeness in Lithuania. Inzinerine Ekonomika-Engineering Economics(4), 20-26.

Kuratko, D. F., Hornsby, J. S., \& Covin, J. G. (2014). Diagnosing a firm's internal environment for corporate entrepreneurship. Business Horizons, 57, 37-47. https://doi.org/10.1016/j.bushor.2013.08.009

Kuratko, D. F., Ireland R. D., Hornsby J. S., \& Covin, J. G. (2005). A Model of Middle-Level Managers' Entrepreneurial Behavior. Entrepreneurship Theory \& Practice, 29, 699-716. https://doi.org/10.1111/j.1540-6520.2005.00104.x

Kuratko, D. F., Montagno, R. V., \& Hornsby, J. S. (1990). Developing an intrapreneurial assessment instrument for an effective corporate entrepreneurial environment. Strategic Management Journal, 11, 49-58.

Lester, D. L., Parnell, J. A., \& Carraher, S. (2003). Organizational life cycle: a five-stage empirical scale. The International Journal of Organizational Analysis, 11(4), 339-354. https://doi.org/10.1108/eb028979

Ling, Y., Simsek, Z., Lubatkin, M. H., \& Veiga, J. F. (2008). Transformational leadership's role in promoting corporate entrepreneurship: Examining the CEO-TMT interface. Academy of Management Journal, 51(3), 557-576. https://doi.org/10.5465/AMJ.2008.32626023

Lumpkin G. T., Cogliser, C. C., \& Schneider, D. R. (2009). Understanding and Measuring Autonomy: An Entrepreneurial Orientation Perspective. Entrepreneurship: Theory \& Practice, 33(1), 47-69. https://doi.org/10.1111/j.15406520.2008.00280.x

Lumpkin, G. T., \& Dess, G. G. (1996). Clarifying the Entrepreneurial Orientation Construct and Linking It to Performance. The Academy of Management Review, 21(1), 135-172.

Lyon, D. W., Lumpkin, G. T., \& Dess, G. G. (2000). Enhancing Entrepreneurial Orientation Research: Operationalizing and Measuring a Key Strategic Decision Making Process. Journal of Management, 26(5), $1055-1085$. https://doi.org/10.1177/014920630002600503

Matson, J. V. (1996). Innovate or Die: A Personal Perspective on the Art of Innovation. USA: Paradigm Press.

McGuire, S. J. J. (2003). Entrepreneurial organizational culture: construct definition and instrument development and validation: doctoral dissertation. Ann Arbor, MI: ProQuest information and learning company.

Miller, D., \& Freisen, P. H. (1982). Innovation in conservative and entrepreneurial firms: Two models of strategic momentum. Strategic Management Journal, 3(1), 1-26. https://doi.org/10.1002/smj.4250030102

Miller, D., \& Freisen, P. H. (1984). Organizations: A Quantum View. Englewood Cliffs, NJ: Prentice-Hall.

Morris, M. H., \& Kuratko, D. F. (2002). Corporate Entrepreneurship. Mason, OH: South-Western College Publishers.

Morris, M. H., Kuratko, D.F., \& Covin, J. G. (2008). Corporate Entrepreneurship \& Innovation, Entrepreneurial Development within Organizations, Mason, OH: Thomson South-Western

Murphy, P. J., Liao, J., \& Welsch, H. P. (2006). A Conceptual History of Entrepreneurial Thought. Journal of Management History, 12(1), 12-25. https://doi.org/10.1108/13552520610638256

Oden, H. W. (1997). Managing Corporate Culture, Innovation, and Intrapreneurship. Quorum Books.

Patterson, D., \& Rolheiser, C. (2004). Creating a Culture of Change. Journal of Staff Development, 25(2), 1-4.

Paulioniene, L. (2007). Verslumo ugdymas profesiniame mokyme. Vocational Education: Research and Reality, 13, 200211.

Peters, T. J., \& Waterman, R. H. (1982). In search of excellence: Lessons from America's best-run companies. NY: Harper \& Row.

Petuskiene, E., \& Glinskiene, R. (2011). Entrepreneurship as the Basic Element for the Successful Employment of Benchmarking and Business Innovations. Inzinerine Ekonomika-Engineering Economics, 22(1), 69-77. https://doi.org/10.5755/j01.ee.22.1.220

Pinchot, G. (1985). Intrapreneuring: Why you don't have to leave the corporation to become an entrepreneur. NY: Harpercollins. 
Pundziene, A., Kundrotas, V., \& Lydeka, Z. (2006). Management challenges in rapidly growing Lithuanian enterprises. Baltic Journal of Management, 1(1), 34-48. https://doi.org/10.1108/17465260610640868

Russell, R. D. (1989). How organisational culture can help to institutionalise the spirit of innovation in entrepreneurial ventures. Journal of Organizational Change Management, 2(3), 7-15. https://doi.org/10.1108/09534818910005773

Russell, R. D. (1990). Innovation in Organizations: Toward an Integrated Model. Review of Business, 12(2), 19-25.

Russell, R. D. (1999). Developing a process model of intrapreneurial systems: A cognitive mapping approach. Entrepreneurship Theory and Practice, 23(3), 65-84.

Russell, R. D., \& Russell, C. (1992). An examination of the effects of organizational norms, organizational structure and environmental uncertainty on entrepreneurial strategy. Journal of Management, 18(4), 639-657. https://doi.org/10.1177/014920639201800403

Rutherford, M. W., \& Holt, D. T. (2007). Corporate entrepreneurship. An empirical look at the innovativeness dimension and its antecedents. Journal of Organizational Change Management. 20 (3), 429-446. https://doi.org/10. $1108 / 09534810710740227$

Rutherford, M. W., Buller, P. F., \& McMullen, P. R. (2003). Human resource management problems over the life cycle of small to medium-sized firms. Human Resource Management, 42(4), 321-335. https://doi.org/10.1002/hrm.10093

Sathe, V. (1985). Managing an Entrepreneurial Dilemma: Nurturing Entrepreneurship and Control in Large Corporations. Frontiers of Entrepreneurial Research, Wellesley, MA: Babson College, 636-657.

Sathe, V. (1988). From Surface to Deep Corporate Entrepreneurship. Human Resource Management, $27(4), 389-411$. https://doi.org/10.1002/hrm.3930270403

Schollhammer, H. (1982). Internal corporate entrepreneurship. In C. A. Kent, D. L. Sexton, K. H. Vesper, (ed.), Encyclopedia of entrepreneurship, pp. 209-229. Englewood Cliffs, NJ: Prentice Hall.

Sharma, P., \& Chrisman, J. (1999). Toward a reconciliation of the definitional issues in the field of corporate entrepreneurship. Entrepreneurship Theory \& Practice, 23(3), 11-27.

Singer, S., Amoros, J. E., \& Arrola, D. M. (2014). Global Entrepreneurship Monitor 2014 Global Report. London: Global Entrepreneurship Research Association.

Snitka, V., \& Gerdvilas, S. (2001). Antrepreneryste ir jos įtaka ekonomikos augimui. Mokslo darbai: Ekonomika, 54, 126133.

Startiene, G., \& Remeikiene, R. (2008). Gender Gap in Entrepreneurship. Inzinerine Ekonomika-Engineering Economics, (5), 95-103.

Stevenson, H. H., \& Jarillo Mossi, J. C. (1990). A paradigm of entrepreneurship: Entrepreneurial management. Strategic Management Journal, 11(4), 17-27.

Stopford, J. M., \& Baden-Fuller, C. (1994). Creating corporate entrepreneurship. Strategic Management Journal, 15(7), 521-36. https://doi.org/10.1002/smj.4250150703

Strazdiene, G., \& Garalis, A. (2007). Edukacines inovacijos “Imitacine verslo imone“ diegimo ypatumai Lietuvos kolegijose. Mokytoju ugdymas, 9, 128-144.

Sykes, H. B., \& Block, Z. (1989). Corporate venturing obstacles: Sources and solutions. Journal of Business Venturing, 4, 159-167. https://doi.org/10.1016/0883-9026(89)90018-9

Turro, A., Urbano, D., \& Peris-Ortiz, M. (2014). Culture and innovation: The moderating effect of cultural values on corporate entrepreneurship. Technological Forecasting \& Social Change, 88, 360-369. https://doi.org/10.1016/ j.techfore.2013.10.004

Urban, B. (2012). The effect of pro-entrepreneurship architecture on organisational outcomes. Journal of Business Economics and Management, 13(3), 518-545. https://doi.org/10.3846/16111699.2011.620153

Uus, I., \& Monkeviciene Z. (2005). Measuring Organizational Openness to Strategic Business Networking. Social Sciences / Socialiniai mokslai, 2(48), 37-44.

Vaitkevicius, S., \& Binkeviciute, G. (2007). Entrepreneriskos organizacijos strategines vertes nustatymo ekonominis modelis. Ekonomika ir vadyba - $2007=$ Economics and management - 2007, 534-539.

Van de Ven, A., \& Poole, M. S. (1995). Explaining Development and Change in Organizations. Academy of Management Review, 20, 510-540. https://doi.org/10.2307/258786

Van Doorn, S., Jansen, J. J. P., Van den Bosch, F. A. J., \& Volberda, H. W. (2013). Entrepreneurial Orientation and Firm Performance:Drawing Attention to the Senior Team. Journal of Product Innovation Management, 30(5), 821-836. https://doi.org/10.2307/258786

Vazdonis, V., \& Ciutaite, D. (2010). Kaimo vietovių ekonominio konkurencingumo ir vietos gyventojų verslumo sąsajos. Management Theory \& Studies for Rural Business \& Infrastructure Development, 22(3), 1-9.

Venkatraman, N. (1989). Strategic orientation of business enterprises: The construct, dimensionality, and measurement. Management Science, 35, 942-962. https://doi.org/10.1287/mnsc.35.8.942 
Vesper, K. H. (1984). Three Faces of Corporate Entrepreneurship: A Pilot Study. Frontiers of Entrepreneurial Research, Wellesley, MA: Babson College, 294-320.

Wang, C. L. (2008). Entrepreneurial Orientation, Learning Orientation, and Firm Performance. Entrepreneurship Theory \& Practice, 32(4), 635-657. https://doi.org/10.1111/j.1540-6520.2008.00246.x

Wickham, P. A. (2004). Strategic entrepreneurship. Harlow: Financial Times Prentice Hall.

Zahra, S., Hayton, J., Salvato, C. (2004). Entrepreneurship in family vs. non-family firms: A resource-based analysis of the effect of organizational culture. Entrepreneurship Theory \& Practice, 28(4), 363-381. https://doi.org/10.1111/j.15406520.2004.00051.x

Zahra, S. A. (1991). Predictors and financial outcomes of corporate entrepreneurship. Journal of Business Venturing, 6, 25985. https://doi.org/10.1016/0883-9026(91)90019-A

Zahra, S. A. (1993). Environment, corporate entrepreneurship and financial performance: A taxonomic approach. Journal of Business Venturing, 8, 319-340. https://doi.org/10.1016/0883-9026(93)90003-N

Zahra, S. A. (1996). Technology strategy and financial performance: Examining the moderating role of the firm competitive environment. Journal of Business Venturing, 11, 189-219. https://doi.org/10.1016/0883-9026(96)00001-8

Zahra, S. A., \& Covin, J. (1995). Contextual influences on the corporate entrepreneurship performance relationship: A longitudinal analysis. Journal of Business Venturing, 10, 43-58. https://doi.org/10.1016/0883-9026(94)00004-E

Zhao, F. (2005). Exploring the synergy between entrepreneurship and innovation. International Journal of Entrepreneurial Behaviour \& Research, 11(1), 25-41. https://doi.org/10.1108/13552550510580825

Zidonis, Z. (2008). Verslumo skatinimo politika Lietuvoje: produktyvi, neproduktyvi ir destruktyvi antrepreneryste. Viesoji politika ir administravimas, 26, 9-16.

Zukauskas, P., \& Stripeikis, O. (2011). Asmens sprendimą pradeti verslą įtakojantys veiksniai. Organizacijų vadyba: sisteminiai tyrimai, 57, 127-141.

Zwell, M. (2000). Creating a culture of competence. USA: John Wiley\&Sons, Inc.

The article has been reviewed.

Received in March, 2015; accepted in February, 2017. 